\title{
THE COMMON-LAW RESPONSE TO THE ACCIDENT COMPENSATION SCHEME
}

\author{
Ailsa Duffy QC*
}

In a scheme that began with rejecting common law, the reappearance of civil litigation on the margins of ACC during the 1980s drew much attention. In line with successive statutory revisions, certain claims (for example, "nervous shock") were excluded from ACC coverage only to be revived within common law. Other claims, including certain types of medical misadventure, were "covered" by ACC but received no benefits in the absence of economic loss, especially as benefit standards were tightened. In addition the bar on compensatory damages for negligence was held not to exclude exemplary damages. This paper explores the vagaries of ACC coverage that reawakened common law during the 1980s and 1990s, with special attention to various health crises involving women.

\section{$1 \quad$ INTRODUCTION}

When the accident compensation scheme was first introduced in 1974 it was heralded by its proponents as a revolutionary new measure which would remove the uncertainty and cost of litigation and encourage early rehabilitation of victims. The Court of Appeal in one of the seminal cases on the early legislation described it as being "designed fundamentally to supplant the vagaries of actions for damages for negligence at common law". ${ }^{1}$ However, the legislation has not always achieved this result. Over the years there has been a retreat from the original comprehensive scheme. With this retreat has come a renewed resort to common law remedies. The results of all this are themselves vagarious. Today, a better description of what prevails is that the recognised vagaries of common law actions for compensatory damages have simply been supplanted by new vagaries. This can be demonstrated by looking at how ACC legislation, in its various permutations over the last 28 years, has provided for women who have suffered personal injury.

Much of the discussion on the deficiencies of ACC legislation over the last twenty years has been generated by various health crises involving women. Women who have suffered personal

* Barrister, Auckland. Ms Duffy was the Chair of the Inquiry in Reporting of Cervical Smears in the Gisborne Region.

1 Green v Matheson [1989] 2 NZLR 564 (CA). 
injury through such crises provide a classic case study for analysing the legislation's defects. This was especially so during the ten year period when lump-sum payments were abandoned. ${ }^{2}$ Even now that they are once again available, the disparity between the amount of compensation payable for personal injury under the Injury Prevention Rehabilitation and Compensation Act 2001 and the quantum of compensatory damages awarded for personal injury in other common law jurisdictions is still a cause for concern.

For those persons who do not earn an income, the legislation's ability to compensate has been diminished: first, by lump-sum payments which failed to keep pace with inflation, and then by the removal of lump-sum payments. The lump-sum payments that have now been re-introduced are not generous, and their focus is more on compensating injuries which interfere with the ability to earn an income. Consequently, injuries which do not result in a loss of income, for example injury to fertility or to female parts of the body, are not satisfactorily compensated. For victims of those injuries a common law action, with all its uncertainties, becomes an attractive option. Hence, lawyers acting for such victims make an enormous effort to avoid cover under the legislation because, if they succeed, the victims can then sue. These attempts result in inequalities of outcomes for injury victims. The changes to the accident compensation scheme, coupled with the common law's response to these changes, have made accident victims participants in a new lottery.

\section{ACCIDENT COMPENSATION ACTS OF 1972 AND 1982}

The earlier ACC legislation of 1972 and 1982 received strong judicial support. Cover depended upon whether or not a victim had suffered personal injury. The definition of personal injury in the 1974 and 1982 Acts was non-exhaustive. The courts responded by giving the term its ordinary and natural meaning. Any "mishap which befell a person" was a personal injury, with the result that anyone suffering such mishap had cover under the legislation.

Attempts to circumvent the legislation's bar against common law actions were thwarted. In Green $v$ Matheson, ${ }^{3}$ a case arising from the mishandling of the treatment of cervical cancer patients at National Women's Hospital, novel causes of action for compensatory damages in breach of fiduciary duty and misrepresentation were brought against the doctors, the health authority and the university (National Women's was a teaching hospital). The usual causes of action for personal injury such as negligence and trespass to the person were also pleaded. For claims in equity and the law of misrepresentation, the purpose of an award of compensatory damages is to remedy the breach of the fiduciary duty and to restore the plaintiff to the position she would have been in but for the

2 Lump-sum payments were an initial feature of the scheme. The Accident Compensation Act 1972 provided for lump-sum payments. So did the Accident Compensation Act 1982. The Accident Rehabilitation and Compensation Insurance Act 1992 removed lump-sum payments. The Accident Insurance Act 1998 made no provision for lump-sum payments. Then in 2002 they were re-introduced by the Injury Prevention Rehabilitation and Compensation Act 2001.

3 Green v Matheson, above. 
misrepresentation. By pleading these causes of action the plaintiff tried to circumvent the legislation's bar against suit.

However, all claims for compensatory damages were struck out. The Court found that the mishandling of the plaintiff's medical case was at the core of all her claims; without that her claims were ill-founded. Since the legislation prohibited all claims arising directly or indirectly from personal injury how the cause of action might be framed was ineffectual. Claims for exemplary damages arising from the same conduct were permitted to proceed as they did not arise from the injury suffered. These claims were ultimately settled.

In Childs $v$ Hillock $^{4}$ an attempt to sue the Minister of Health for permitting intra-uterine devices (IUDs) to be used without proper inquiry into their effects was struck out for similar reasons. More then 30 women had suffered pelvic inflammatory disease, and some had been rendered sterile by the use of the devices. Each woman brought her own claim. Ms Childs' claim was used as a test case to determine if a common law action was prohibited by the legislation.

The action against the Minister was that he had breached his duties under the Medicines Act 1981 by permitting the use of a contraceptive device which had damaging effects on women's health. The plaintiffs attempted to avoid the bar against suit by not claiming against the medical practitioner responsible for inserting the IUDs. Their claims were against the manufacturers of the devices, and the Minister of Health for approving their use. This stratagem failed. The Court found that the failure to allege fault against the party primarily responsible for the injury had no effect on the legislation's application. In addition, it found that there could be personal injury by accident even where no one was responsible. For the purpose of determining whether or not the prohibition against suit applied, all that needed to be looked at was whether or not a personal injury had in fact been sustained. If it had, that was enough to bring the injury within the legislation's scope. As long as the true nature of the claim was one for personal injury, that was enough to activate the statutory bar, irrespective of how the claim was pleaded and against whom. ${ }^{5}$

The no-fault principle made causation irrelevant. To qualify for compensation under the 1974 and the 1982 legislation there was no need to identify a causative event. In Accident Compensation Corporation $v E^{6}$ an employee who suffered a mental breakdown after attending a stressful management course was found to be eligible for compensation. After being on the course for four days she suffered a psychotic episode. No triggering event could be identified. That however was unnecessary since all that the Act required was "personal injury by accident not by an accident".

4 Childs $v$ Hillock [1994] 2 NZLR 65 (CA).

5 Childs v Hillock, above, 73.

6 Accident Compensation Corporation v E [1992] 2 NZLR 426 (CA) [ACC v E]. 
In Brownlie v Good Health Wanganui ${ }^{7}$ a pathologist misread the plaintiffs' breast histology as benign when in fact it was malignant. The plaintiffs sued for compensatory damages in negligence and breach of fiduciary duty. Their counsel argued that the ACC legislation did not apply to them because the negligence stemmed from a negligent failure to treat rather than from negligent treatment; the women were described as "sick and getting sicker". The defendants argued that if the women were sick as a result of the pathologist's negligence, this was due to his misdiagnoses of their histology. As this was no more than a mishandling of their medical cases they were covered by the ACC legislation and their claims should be struck out. They were.

Having cover under the legislation gave the female victims in Childs and Brownlie little comfort. The pelvic inflammatory disease suffered by Ms Childs, and the other women who had filed similar claims, did not affect their ability to earn an income and so they were not eligible for earnings-related compensation. It did affect their ability to conceive a child, but by the time their claims were brought lump-sum payments had been abolished. The plaintiffs in Brownlie and their families had to live with the knowledge that the misdiagnoses may have put their recovery at risk. Most were middle-aged women who had spent their adult life primarily as homemakers. This circumstance meant that they were not eligible for earnings-related compensation. Since lump-sum payments were no longer available these women received no financial compensation for their loss.

\section{ACCIDENT REHABILITATION AND COMPENSATION INSURANCE ACT 1992}

Lump-sum payments were abolished by the Accident Rehabilitation and Compensation Insurance Act 1992. The passing of this Act was a reaction to claims brought under the earlier legislation. Judgments on the earlier legislation had found that once a personal injury by accident was established all the emotional and mental consequences which followed were also part of the injury; there was no need to connect or to identify those consequences with any particular mental condition. This resulted in a flood of claims for lump-sum payments for pain and suffering arising from sexual abuse. To stem this flood the 1992 legislation removed the right to all lump-sum payments. This brought to an end the bulk of the compensation claims by sexual abuse victims. These claimants relied heavily on lump-sum payments, as do other claimants whose injury does not prevent them from working. It also meant that women who were not employed, but who suffered injury from a crisis in the health system, like the unfortunate experiment at National Women's Hospital or the women with misdiagnosed breast cancer at Good Health Wanganui, no longer received any financial compensation

The 1992 Act restricted cover in other ways. First, it tightened the definition of personal injury by setting out an exhaustive series of definitions for personal injury by accident and by medical misadventure. The move away from a non-exhaustive definition, which captured all mishaps to the

7 Brownlie v Good Health Wanganui (10 December 1998) Court of Appeal CA 64/97, Henry J. 
person, was done to avoid the outcome of cases like $A C C v E^{8}$ where the Court had said there was no need to identify a causative event. Proof of causation became a prerequisite for cover under the Act. Secondly, it excluded from cover injuries that were purely mental. Mental injury was only covered if it flowed from a physical injury.

The transitional provisions of the 1992 Act were draconian. Injuries suffered after the 1992 Act were covered by that Act alone. If there was no cover the victim was free to sue. Where an injury occurred prior to the 1992 Act, but no claim was lodged until the passing of the 1992 Act, a different set of circumstances arose. In this case if a person had cover under the earlier legislation he or she had twelve months in which to lodge a claim. Then the claim was dealt with as if the earlier legislation remained in force. But if no claim was lodged within the twelve-month transitional period, entitlement to compensation was determined by the more restrictive 1992 Act. If there was no entitlement under that Act, there was no entitlement to compensation irrespective of their rights under the earlier legislation. Despite their loss of compensation rights under the old legislation, the prohibition in that legislation against common law claims for compensatory damages was continued by the new Act. For victims in this category the new legislation gave them nothing and the old legislation lived on, in so far as it prevented them suing for compensatory damages. To retain their rights to compensation under the old legislation they had to lodge a claim by 1 October 1992. ${ }^{9}$ Those who qualified under the old legislation but only learnt of their injury after that date were left without any remedy. There was no test of reasonable discoverability as there is under the common law. Hence women who only learnt many years after the event that they had been victims of negligent medical treatment were left without any financial remedy.

\section{A Inadequacy of Lump-Sum Payments}

The plight of women in cases like Green, ${ }^{10}$ Childs $^{11}$ and Brownlie ${ }^{12}$ raised serious questions about the legislation's benefit. If the purpose of an accident compensation scheme was to remove the vagaries of the common law including the uncertainty and cost of litigation, and the need to prove fault, why had the ACC scheme failed these women? Why did they strive to avoid the scheme's cover? What did the common law offer them that made it look so attractive?

Under the 1972 and the 1982 legislation the range of compensation was broader than under the 1992 and 1998 legislation. However, women were dissatisfied with the earlier legislation as well as the later. It is too soon to tell what impact the restoration of lump-sum payments will have on how

\footnotetext{
$8 \quad A C C v E$, above.

9 Accident Rehabilitation and Compensation Insurance Act 1992, s 135.

10 Green v Matheson [1989] 2 NZLR 564 (CA).

11 Childs $v$ Hillock [1994] 2 NZLR 65 (CA).

12 Brownlie v Good Health Wanganui (10 December 1998) Court of Appeal CA 64/97, Henry J.
} 
the legislation is now perceived. I do not think it will be an improvement for women victims as the lump-sum payments focus on injuries such as loss of eyes, limbs, and fingers which affect moneyearning capacity. Uteri and breasts are not listed in the Act's schedule of body parts.

Under the 1972 and 1982 Acts the availability of lump-sum payments meant the certainty of payment of some compensation replaced the right to sue. However, from the victim's perspective one of the drawbacks of the legislation was the low level of the lump-sum payments. They had failed to keep pace with inflation. Under section 78 of the Accident Compensation Act 1982 the maximum lump-sum payment for non-economic loss for permanent loss or impairment of bodily function was $\$ 17,000$. Under section 79 the maximum lump-sum for non-economic loss of enjoyment of life and pain and suffering was $\$ 10,000$. The First Schedule to the Act specified a percentage of $\$ 17,000$ which would be paid for the loss or impairment of particular body parts. Section 78(3) enabled the Commission to make a lump-sum payment where the injured body part was not specified in the First Schedule; however the amount paid was not to exceed $\$ 17,000$. The First Schedule did not attempt to place a percentage value on female body parts related to fertility.

Like Mrs Matheson, many of the women who were part of the unfortunate experiment at National Women's Hospital were not treated for their pre-cancerous cervical abnormalities as early as they should have been. They turned up for what they believed was treatment, but without their knowledge they had been placed in a group whose abnormalities were simply being observed; they did not receive the earliest possible medical intervention for their condition. They were intentionally denied appropriate early medical treatment because of Professor Green's theory that untreated pre-cancerous abnormalities of the cervix seldom progress to cervical cancer. These women never knew that they were part of an experiment to test his theory. They believed that they were being treated appropriately and that everything was being done to cure their disease. Some of them went on to develop cervical cancer; others developed high-grade pre-cancerous abnormalities which required far more invasive treatment than would have been necessary if treatment had commenced shortly after diagnosis.

There were perhaps two forces driving these women to sue. First, their desire to hold the doctors and hospital authorities accountable for their errors, and secondly, their dissatisfaction with the compensation payable under the Act. The notion that mishaps are a part of modern life and that no fault or blame should be attributable to those responsible was perhaps too hard for the women to take, given the circumstances of their injuries. An accident compensation scheme based upon a principle of no fault is unable to provide the necessary accountability processes that persons who suffer medical misadventure often seek. They want acknowledgement of the wrongdoing to themselves and to ensure that it never happens to others.

I also think that for many of these women the lump-sum payments offered to them must have seemed derisory. Many of them were not employed. Cervical abnormalities tend to occur in middle-aged women and these women are less likely to be in full-time employment. The prognosis for cervical cancer is not good. Unless treated quickly it will result in death. Those who survive will 
be left without a uterus and often without ovaries as well. During the Inquiry into the Reporting of Cervical Smears in the Gisborne Region ${ }^{13}$ I learnt of women with cervical cancer who had suffered complete pelvic clearances in an attempt to remove the cancerous tissue from their bodies. Their bowel and bladder functions had become dependent upon plastic bags. These consequences, which are part of the standard treatment of cervical cancer, had a detrimental impact on the marriages of some. However, once the surgery has healed the loss of these organs is not likely to prevent employment, so that any women who were previously employed would not have received earningsrelated compensation for long.

In a negligence action for medical misadventure the prime risk the plaintiff carries is the burden of proving that the defendant has acted negligently. Once a duty of care and causation are established, liability is proved. There is still the need to quantify damages, however, the common law takes into account non-economic loss when quantifying compensatory damages for personal injury. Whether or not the case can be proved and damages won is a risk the plaintiff must take. Under the ACC legislation plaintiffs like Mrs Matheson faced no such risk. Those who had spent their lives at home as wives and mothers knew for certain that all they would receive at most (medical treatment and rehabilitative care aside) was a lump-sum payment, based upon the Accident Compensation Commission's assessment of an appropriate percentage of $\$ 17,000$ for loss of body parts and a similar percentage of $\$ 10,000$ for pain and suffering. For those men who lost their wives to cervical cancer section 82 of the 1982 Act provided a maximum lump-sum of $\$ 4,000$; those children who lost their mothers to cervical cancer were entitled to $\$ 2,000$ with a maximum cap of $\$ 6,000$.

\section{B Deterioration after 1992}

If the plight of the women mentioned above looks bad, for the women injured in medical crises in the health system from 1992 onwards it was worse. The loss of lump-sum payments meant that persons who were not wage earners and who suffered a personal injury received nothing other than medical and rehabilitative care, if appropriate. Bell $v$ Wanganui Good Health ${ }^{14}$ is a case in point. The women in this case were misdiagnosed as having cancer with the result that they received unnecessary surgery. Those who were misdiagnosed with breast cancer lost a healthy breast unnecessarily. Others misdiagnosed with cervical cancer received unnecessary invasive uterine surgery. There was nothing wrong with any of them. The surgery they suffered did not result in ongoing physical damage that required more treatment; but it did result in physical disfigurement.

13 The writer chaired the Committee of Inquiry. Ailsa P Duffy, Druis K Barrett, Maire A Duggan Report of the Ministerial Inquiry into the Under-reporting of Cervical Smear Abnormalities in the Gisborne Region (Ministry of Health, Wellington, 2001) <http://www.csi.org.nz $>$ (last accessed 3 May 2003).

14 Bell v Wanganui Good Health (1997) 1 BACR 344 (HC). 
Under the 1992 Act there were no financial benefits for which they qualified. Most of the women were not wage earners. In any event their injuries did not interfere with their ability to work. Irrespective of the negligence of the medical practitioners and of the hospital responsible for their medical care, these women received nothing under the legislation other than medical care to correct the injury. They reacted to their predicament by suing for exemplary damages. Their case settled.

One of the effects of the 1992 Act was that victims began to spend much time arguing that it did not apply to them while defendants argued that it did. Defendants saw the Act as giving them immunity from legal proceedings. In Brownlie ${ }^{15}$ the defendants argued that the plaintiffs had cover under both the 1992 Act and the earlier legislation. The Accident Compensation Corporation also appeared before the High Court and argued the plaintiffs were covered under the 1992 Act. It was the plaintiffs who argued they were not covered, as they wanted to be able to sue for compensatory damages. For some, the misdiagnosis of their condition had occurred prior to the 1992 Act. However, they had not learnt of the misdiagnosis until after the expiry of the transitional provision in the 1992 Act. This meant that they were no longer able to receive any lump-sum payment.

Under the previous common law there may have been a lottery as to the amount of damages awarded, and whether or not the defendant could pay. But once a plaintiff established negligence, then, provided the defendant had the means to pay, a plaintiff would at least get something. Between 1992 and 2002 non-wage earners or those wage earners who suffered injuries which did not disable them from working received no monetary payment. This was irrespective of whether or not the injury they suffered had been caused by the fault of someone else. For these persons the lottery of litigation has been replaced with the certainty of knowing that they would receive no financial payment under the legislation for their loss.

It is for this reason that this category of victims will either attempt to avoid the Act's cover, or if they cannot do that, they will sue for exemplary damages or attempt to isolate their physical injuries from any mental injury they have in the hope of bringing a claim based upon nervous shock. They do this because the ACC legislation offers them little or nothing in the way of compensation, whereas under the common law they have the chance of receiving compensatory damages. In addition, many of these victims harbour a sense of grievance against the defendants. They want an acknowledgment that they have been poorly treated and for the persons responsible to be held accountable.

\section{Lessons from the Gisborne Inquiry}

One of the aims of the ACC scheme was to rehabilitate victims quickly; the common law was said to give little incentive for a quick recovery as a plaintiff's condition at the time of the trial

15 Brownlie v Good Health Wanganui (10 December 1998) Court of Appeal CA 64/97, Henry J. 
influenced the level of damages awarded. However, the experience of having to live in financially strained circumstances knowing that the physical disfigurement or other effects of invasive surgery were needless, and the result of negligence, is also not conducive to recovery. Many victims want to ensure that others do not suffer the same fate. The public exposure which results from litigation often brings incidents of poor performance to the surface. For example, the possibility of cervical smears from the Gisborne Region being misread at an unacceptable level came to light through the publicity associated with an exemplary damages claim for negligence against Dr Bottrill. Once the media reported on this case, the health authorities came under greater pressure to investigate and it became less easy to discount what had happened as being an acceptable incidence of false reporting.

Many of the women who gave evidence before the Gisborne Inquiry described themselves as suffering from mental depression as well as the physical effects of the invasive treatment they had received. Their husbands were also depressed. One married woman of 27 , who had suffered a radical hysterectomy and pelvic node dissection to treat early cancer of the cervix (an unusual disease in one so young) and who had during the relevant period undergone regular cervical smear tests (some of which had been misread), feared her inability to have children would cause the end of her marriage. She is reported as having told the Committee "I worry because [my husband] is still able to have his own biological children and I do not know what this will do to our relationship". ${ }^{16}$ She and her husband had delayed having children until they were financially secure. This woman had also suffered the physical pain which accompanies cervical cancer and its treatment. Her cancer was also a reminder to her husband of the death of his cousin from cervical cancer. The injury this woman had suffered was something that she and her family lived with daily. Another woman learnt she was suffering from cervical cancer when her fourth child was four days old. The Inquiry was told that her condition was likely to be terminal; her marriage had broken up under the strain of her ill health and she had four children to provide for. The youngest would now be six years old. ${ }^{17}$

The Committee of Inquiry's Report concluded that there had been an unacceptable level of misreporting by Dr Bottrill. Large numbers of women were affected. Women who had participated in the Cervical Screening Programme by having a cervical smear once every three years, and who originally had been told that their smears were normal, now found that that was not so. The impact of the misreporting of their smear tests meant that often by the time the abnormality was discovered, it had progressed to a higher grade pre-cancerous abnormality or to cervical cancer. The result at best was that they had to suffer more invasive medical treatments. At worst, they learnt their condition was already terminal. The women sought compensation. However, the Report concluded that they had suffered a medical misadventure and were covered under the Accident Insurance Act 1998. This meant that they could not sue and therefore, in the Committee's view, they were not eligible for compensatory damages. The question of whether they should nevertheless receive an $e x$

16 Duffy, Barret, Duggan, above, para 3.29.

17 Duffy, Barrett, Duggan, above, para 3.22. 
gratia payment to compensate them for their injuries was beyond the Inquiry's terms of reference and left to the Government to decide.

The Committee knew that most of the women affected had no financial entitlements under the legislation. Those who were not wage earners would not be eligible for earnings-related compensation. Medical treatment and rehabilitative care were the most that they were likely to receive. The Committee referred to the likelihood of such victims in other common law jurisdictions receiving large financial sums to compensate them for their injuries. In one of the early High Court hearings on patients A's claim against Dr Bottrill, Young J had said: ${ }^{18}$

I have no doubt that Dr B was guilty of negligence. Indeed, it would be open to a court to find negligence on the basis of one badly read slide ... In jurisdictions where compensation is available on the establishment of fault, Mrs A would undoubtedly recover substantial damages for both her economic and non-economic loss.

\section{Mental Injury Cases}

Since 1992 the ACC legislation has excluded from cover injury which arises solely from mental injury. Only those mental injuries associated with a physical injury are now covered. The narrower definition has been seized upon by some as a window of opportunity to enable common law actions for damages. It is an opportunity which has been taken by primary and secondary victims. Primary victims must be able to prove that they have suffered no physical injury; otherwise they will be covered by the legislation. This raises the possibility of disputes over the nature of the injury suffered, where the plaintiff asserts that there is no physical injury associated with his or her mental injury and the defendant asserts that there is. Secondary victims need to satisfy the law relating to claims in negligence for nervous shock.

In Brownlie ${ }^{19}$ the women patients attempted to differentiate between the original injury which they suffered when misdiagnosed (namely the failure to treat them), and the mental injury they suffered during the period of time spanning from when they learnt from the news media that they may have been misdiagnosed, until their condition was confirmed. The Court of Appeal upheld the lower court's decision striking out the claim, but gave leave to the plaintiffs to file an amended statement of claim pleading a separate injury of mental trauma. This was alleged to have occurred during the narrow time-span while the women waited to find out if they were among the misdiagnosed patients. The case has now settled. In my view, the Court of Appeal took this approach so as to enable the women to have some means of redress.

The decisions the Court of Appeal issued that year approach this type of case differently from the early decisions. No longer did there seem to be the same willingness to uphold the legislation's

$18 A v B(28$ March 1999) High Court Auckland CP 310/96 Young J.

19 Brownlie v Wanganui Good Health (10 December 1998) Court of Appeal CA 64/97 Henry J. 
spirit. Queenstown Lakes District Council v Palmer ${ }^{20}$ was decided shortly before Brownlie. In Queenstown Lakes District Council the Court of Appeal held that the statutory bar against suing in section 14 of the 1992 Act did not prevent Mr Palmer from suing for compensatory damages for the nervous shock he suffered in seeing his wife drown on what he alleged was a negligently operated river rafting expedition. Under the earlier legislation he would have received compensation for the mental trauma he suffered in witnessing her death. He would not have been able to sue. However, as the 1992 Act had removed cover for mental injury, he could sue.

Queenstown Lakes District Council showed the emerging signs of a judiciary prepared to recognise that common law rights should be allowed to develop freely unless expressly restricted by legislation. An earlier decision in the High Court, Kingi v Partridge, ${ }^{21}$ had interpreted the statutory bar against suing so widely that it was seen to exclude compensatory damages claims for nervous shock by persons witnessing the physical injury of someone else. The reasoning behind this approach was that the 1982 Act barred all claims arising indirectly from the injury of any person. By 1998, the Court of Appeal in Queenstown Lakes District Council was prepared to take a different approach. The ACC scheme was no longer seen as something which entirely replaced common law claims for damages. The scheme was now seen as standing alongside the common law. The common law adjusted as and when the scope of the Act expanded or contracted. It seems that the Court was not prepared to stand by and see someone who had suffered an injury receive nothing, if it could help it.

Judicial willingness to act in order to avoid injustice, where possible, only started after the 1992 legislation. Bryan $v$ Philips New Zealand Ltd ${ }^{22}$ is an interesting case which demonstrates a court taking a creative approach. The plaintiff was at risk of developing asbestosis as a result of exposure during his employment. The exposure had occurred before the introduction of the ACC legislation. However, section 17 of the 1992 Act deals specifically with asbestosis claims which arise both before and after the 1974 Act. The section imposed a time limit which required all persons alleging injury from exposure to asbestos in the work place either to seek cover under the Act or to bring proceedings before 1 April 1993. Asbestosis is a slow disease which can take many years before it manifests. By 1 April 1993 Mr Bryan had not developed the disease but he had all the signs of someone who would do so. In a strike out application the defendant argued that because Mr Bryan had not developed the disease, he had suffered no loss and therefore he had no claim in negligence. Mr Bryan's claim was premature but that was brought about by the statutory deadline imposed by the legislation. It followed that his claim alleging damage was premature. The Court was clearly reluctant to strike out a claim in these circumstances. Its response was to leave open the possibility

20 Queenstown Lakes District Council v Palmer [1999] 1 NZLR 549 (CA).

21 Kingi v Partridge (2 August 1993) High Court Rotorua CP 16/93 Thorp J.

22 Bryan v Philips New Zealand Ltd [1995] 1 NZLR 632 (HC). 
of a claim for cancerophobia; the fear of developing cancer. The Court described the effect of the ACC scheme as having caused the common law to stand still since the scheme came into force. Fear of cancer was recognised as a head of damage in American cases. The court would not rule it out as a form of actual damage which the plaintiff was already suffering.

The withdrawal of ACC cover for mental injury and the subsequent development of common law claims for nervous shock or other mental injury have created an anomaly. For example, in Queenstown Lakes District Council, if Mrs Palmer had survived her rafting accident but suffered severe physical injury, she could not have sued, as she would have been covered under the 1992 Act. She would have received free medical care; however, there would have been no lump-sum payment to compensate her for her injury. As she was a foreign tourist in the country for a short time, earnings-related compensation would have been of no real value. ${ }^{23}$ The Act offered her little benefit by way of compensation. In this circumstance, had Mr Palmer suffered the same degree of mental trauma in seeing his wife badly injured as he did in seeing her drown, he could have proceeded with an action for compensatory damages. Provided he could have proved negligence against the defendant, he would have received compensation for the shock he suffered in seeing his wife severely injured, while she would receive no financial compensation for her pain and suffering.

\section{E A Setback to Activism}

The hope that decisions such as Queenstown District Lakes Council and Brownlie signalled the presence of an activist court, willing to use the common law to make up for inadequacies in the accident compensation scheme, faded with the decision in Van Soest $v$ Residual Health Management Unit. $^{24}$ In that case the Court of Appeal made it clear that nervous shock claims could only be brought where the victim suffered a psychiatric illness, had been in close physical proximity to the primary victim's accident, and the relationship between the primary and the secondary victim was close. If the pleading did not allege facts which met these criteria, it would be struck out.

The judgment rejected any expansion of the law of nervous shock claims to allow next of kin to claim compensatory damages for mental suffering caused by their awareness of the death or injury of the primary victim. The plaintiffs (secondary victims) were relatives of the deceased patients of Dr Ramstead. The death of these patients precluded any claim by them or their estate, for exemplary damages. The Law Reform Act 1936 precludes an action for exemplary damages by the estate of a deceased person. The only way in which the relatives could take any action against $\mathrm{Dr}$ Ramstead and, if successful on the facts, obtain some public recognition of his alleged ineptitude was through an action based upon nervous shock. Their failure to achieve this result meant that they could not demonstrate that their deceased relatives had been victims of negligence.

23 Earnings-related compensation was only payable while the recipient remained in New Zealand.

24 Van Soest v Residual Health Management Unit [2000] 1 NZLR 179 (CA). 
The rise of the nervous shock claim has seen litigation commenced and then settled. Irrespective of the complexities of the requirements for nervous shock cases (has it given rise to a psychiatric illness? how immediate was the viewing of the incident?) there are some cases which on the merits are best settled. For example, in Auckland a negligence case was settled in 1999 shortly before it was due to start before a civil jury. A mother and father had watched hospital nurses inflate their child with oxygen to the point where the child died. The parents had not suffered a recognisable psychiatric illness as a result of their experience; nevertheless the defendant was obviously concerned about having the facts of the case decided by a jury. No doubt under the present law the pressure to sue in cases such as this will continue. Provided a case can survive a strike out, which to some extent depends upon how well the case is pleaded, the merits will have a strong influence on its outcome. ${ }^{25}$ Such cases may settle through fear of a sympathetic verdict in favour of the plaintiff. While this may be good for plaintiffs who make the grade, it leads to erratic outcomes.

\section{F Exemplary Damages}

The rise in exemplary damages claims is also a response to the inability to sue for compensatory damages in circumstances where often the accident compensation scheme provides little or no financial remedy.

Initially it seemed that there was a judicial trend towards accepting claims for exemplary damages. Historically such damages had been unavailable for unintentional torts. However in McLaren Transport $v$ Somerville $e^{26}$ and $A v B^{27}$ the High Court was prepared to accept that exemplary damages were available in negligence if gross negligence was established. Both cases were heard by a judge alone. In the first damages were awarded. In the second they were not, as the negligence was held not to be sufficiently gross.

But by 1998 the Court of Appeal in Daniels v Thompson ${ }^{28}$ indicated that it was not prepared to see exemplary damages become a stop-gap for the lack of availability of a compensatory remedy. The claim in this case was based upon the defendant having sexually abused the plaintiff. The Court of Appeal found that exemplary damages were not available when a defendant had already been acquitted or convicted of criminal charges relating to the same conduct. Oddly enough, the legislature responded by passing legislation which reversed the effect of the ruling in Daniels $v$

25 In a strike out it is assumed that the allegations pleaded are capable of proof. Therefore, so long as the criteria for a nervous shock claim are pleaded it should survive a strike out. Proof of the allegations is left to the trial. It then becomes a test of the defendant's nerve as to whether or not to put a plaintiff to proof, especially before a jury which may be less interested in legal complexities.

26 McLaren Transport v Somerville [1996] 3 NZLR 424 (HC).

$27 A v B(28$ March 1999) High Court Auckland CP 310/96 Young J.

28 Daniels $v$ Thompson [1998] 3 NZLR 22 (CA). 
Thompson. ${ }^{29}$ Seemingly, it considered that victims of sexual abuse should be able to bring common law claims for some form of damages.

Later, in $A v$ Bottrill, ${ }^{30}$ the Court of Appeal revealed the same reluctance to allow exemplary damages to fill the gap created by the combined effect of the accident compensation's limited entitlements and its prohibition against suit. In that case it concluded that exemplary damages should only be available where "the defendant is subjectively aware of the risk to which his or her conduct exposes the plaintiff". What was required was "some conscious creation of, or persistence in, an unsafe system knowing that there is a substantial risk of harm to the plaintiff or someone in his or her position".

However, the Privy Council has reversed the decision. It found that as a matter of principle cases of intentional or consciously reckless conduct should not be distinguished from those where the conduct was unintentional. The basic question for the purposes of exemplary damages was whether or not the presiding judge considered the defendant's conduct to be "so truly exceptional and outrageous that an award of exemplary damages is called for". ${ }^{31}$ The Court of Appeal's view that, unless tightly restricted, exemplary damages claims would undermine the accident compensation scheme, was nicely dealt with. Usually the Privy Council is reluctant to interfere with a local Court's views on policy and social considerations. But in Bottrill the Privy Council was able to substitute its views on such considerations because it found that the Court of Appeal's evaluation had proceeded on a mistaken basis. It had approached the policy question on the basis that legal principle required an advertent conduct - the only limitation. This was wrong. The opposite was the case. The real question involved evaluating policy considerations on the basis that imposing this limitation would be a departure from basic principle.

The Court of Appeal's decision in Av Bottrill demonstrates an overly-stringent approach to the availability of exemplary damages for unintentional torts. The Privy Council's decision pulls the test for exemplary damages back to where it was in McLaren Transport. Their Lordships were careful to emphasise that exemplary damages will be awarded only in exceptional cases and that such awards "in the absence of intentional wrong doing or conscious recklessness will be rare and exceptional". ${ }^{32}$ Also the decision includes the reminder that "a perceived need for compensation, or further compensation, is not a proper basis for making an award of exemplary damages". Despite this admonition, the removal of the advertent conduct limitation is likely to give hope to future plaintiffs wanting to call a tortfeasor to account.

29 Accident Compensation Act 1998, s 396.

30 A v Bottrill [2001] 3 NZLR 622 (CA).

$31 A v$ Bottrill [2002] 3 WLR 1406; (2002) 7 NZBLC 103, 796 (PC).

32 A v Bottrill, $\mathrm{PC}$, above. 


\section{G Jury Trials}

For those cases which survive a strike-out, the availability of jury trials puts pressure on defendants to settle. In circumstances where the jury is being asked to assess exemplary damages practitioners are nervous about how a jury will react. From the plaintiff's perspective the hope of a sympathetic verdict has to be weighed against the concern that a more analytical application of the legal tests will occur. From the defendant's perspective the converse applies. Assessing how a jury will react to these cases is a difficult task.

Some plaintiffs are electing to have their exemplary damages claims determined by civil juries although, to my knowledge, no case has gone to trial yet. However, the use of a jury hangs like the sword of Damocles over the heads of many defendants. In $L v M^{33}$ the High Court upheld the plaintiffs' right to have the claim tried before a judge and jury. Under section 19A of the Judicature Act 1908 where the relief sought is damages alone the onus is on the party resisting trial by jury. In $L v M$ the claim was based upon an employer's vicarious responsibility for the acts of sexual abuse which its employee had committed. The causes of action included negligence and breach of fiduciary duty. The case settled.

New Zealanders are now well aware of the limitations of the ACC scheme. Few lawyers would predict how a jury might react in negligence actions for exemplary damages or compensatory damages for nervous shock when the defendant is clearly at fault and the plaintiff has no other means of obtaining compensation. This is something which troubles most practitioners. The result is that much of the argument is raised in strike-out applications. If the case survives a strike out it will most likely settle.

One such case demonstrates the pressure to settle, when the facts are bad, as well as the vagaries of a system which allows secondary (but not primary) victims to sue for compensatory damages. A mental health patient on leave from hospital sodomised a boy in front of his brother. On the principle in the Dorset Yacht $\mathrm{Co}^{34}$ case an action was brought against the relevant mental health authority as well as the patient. The abused boy could only sue for exemplary damages and so faced the rigorous test of proving they were justified. The brother who had observed the abuse was able to sue for compensatory damages based on nervous shock. He faced a lower test. Had this case gone to trial, there would have been two different tests for the awards of damages arising from the same incident, and the person who suffered the greatest injury would have had to satisfy the more onerous test.

One of the features of an exemplary damages claim is that it can only be brought by the victim. Once the victim is deceased, there is no right to exemplary damages. To take the example of the

$33 L v M(1998) 11$ PRNZ 630 (HC).

34 Dorset Yacht Co Ltd v Home Office [1970] AC 1004 (HL). 
case of $A v$ Bottrill, the Privy Council has advised that her claim should proceed. ${ }^{35}$ However, there are other Gisborne women with misread smears whose medical cases were probably no different from A's. They will not be able to bring a claim for exemplary damages because in their cases the discovery of their misdiagnosed disease was too late to be treated successfully. They have died. If they died as a result of medical negligence on Dr Bottrill's part he cannot be called to account.

\section{H Other Vagaries}

There are other vagaries which result from the limitations of the accident compensation scheme and its statutory bar against common law compensatory damages claims. These include use of criminal and summary prosecutions, use of professional disciplinary processes, use of public inquiries, and use of ex gratia payments, which often follow on from public inquiries.

In New Zealand there have been a number of medical manslaughter cases. Other manslaughter cases have arisen from unsafe work practices. Growing concern about the use of manslaughter charges in this way has resulted in the Crimes Act 1961 being amended to impose a higher standard of care for criminal negligence. Section 150A imposes a standard of gross negligence whereas under section 156 the standard was ordinary civil negligence. However, there is no recognition of contributory negligence in criminal law. It is enough if the unlawful act or omission was a substantial cause of death. The use of the criminal law as an alternative to a civil claim for negligence places additional burdens on the defendant and deprives him or her of defences available in the civil law. The appropriateness of using the criminal law in this way is open to question.

Another attempt by the courts to give victims some form of compensation occurs in Health and Safety Act 1992 prosecutions, where fines imposed are often directed to be paid in whole or in part to the victim. This legislation has recently been amended to allow victims to bring prosecutions. However, a prosecution under this Act can only be brought for workplace injuries. If the injury occurs at work and the employer is to blame the victim has the chance of a monetary payment. Injuries outside of work are not covered. Once again, the payment of money for injury becomes a lottery.

In relation to medical misadventure there has been pressure on the medical profession and on the Government to improve the profession's disciplinary processes. This has led to the creation of the role of the Health and Disability Commissioner and the development of the Medical Disciplinary Tribunal. Disciplinary processes have been used as a substitute for a common law action to enable a victim to obtain some acknowledgement of having been wronged.

35 A v Bottrill (6 September 2002) Privy Council PCA 10/2002 Lord Nicholls of Birkenhead. 
There is also the use of settlements when it would be too unpopular to rely upon the statutory bar against suit - for example: the settlement of the Cave Creek disaster. ${ }^{36}$ Those who lost loved ones in this disaster may consider the compensation they received to be entirely justified. However, what it means is that if an accident has a sufficiently high profile and has the potential for political embarrassment a lump-sum payment ex gratia may be made. The outcome of the inquiry into the injury to neonatal babies at National Women's Hospital gave rise to similar pressure. I am aware that the women who were affected by the misreporting of cervical smears in Gisborne are pressing for payment of compensation. In all cases the accident compensation scheme prohibits suing for compensatory damages. Whatever the sympathy one feels for such victims to give them ex gratia payments is to treat them differently from accident victims in general. This is not even-handed treatment. It offends the principle that like cases should be treated alike. The departure from this principle has created a lottery of its own.

\section{The Influence of a "No-Fault" Principle}

The influence of a "no-fault principle" on human behaviour requires consideration. I know of no research into this question and so my comments are based purely on personal experience. After the exemplary damages claim against Dr Bottrill received press coverage, the pressure for a general re-reading of Gisborne women's smear tests became irresistible. There had been murmurings of the need for a general re-reading of cervical smears read by Dr Bottrill before Young J's decision. ${ }^{37}$ However, after the decision became public the Health Funding Authority appointed a committee to advise on this question, and it concluded that there should be a re-reading of the smears. The open hearings of the Inquiry brought to public attention the lack of clear regulation of laboratory standards: there was no compulsory quality assurance until 1997 (the smears were misread between 1990 to 1996), there was no compulsory peer review, although most pathologists thought this advisable, and there was nothing to stop a pathologist operating as a sole practitioner performing every step of the smear-reading process himself so that there was no "second pair of eyes" to detect any mistakes. Without a public hearing I think it unlikely that these facts and their implications would have emerged so clearly. In that regard a judicial or quasi-judicial process where evidence is given publicly and is subject to cross-examination can have salutary benefits for learning what went wrong. I also think that the threat of this process, which the ability to litigate brings, helps to regulate conduct.

I wonder how insurers would have reacted to Dr Bottrill's method of practice. If Dr Bottrill had been vulnerable to a common law damages claim for compensatory damages his insurers may have encouraged a different type of practice. The evidence before the Gisborne Inquiry was that his

36 The outcome of the Committee of Inquiry into the loss of life at Cave Creek revealed that the Department of Conservation had much to answer for. "Commission of Inquiry into the Collapse of a Viewing Platform at Cave Creek near Punakaiki on the West Coast, 1995" [1993-96] XL AJHR H2.

$37 A v B$ (28 March 1999) High Court, Auckland CP 310/96 Young J. 
practices were inadvisable and risky. I wonder whether or not Dr Bottrill would have adopted the same practices if he had known that he could be sued for compensatory damages in negligence. As Dr Bottrill was never questioned on this matter any answers would be speculative; however, such questions should provide lawyers and legislators with food for thought.

\section{THE CURRENT REGIME}

It is too early to predict whether or not the passing of the Injury Prevention, Rehabilitation and Compensation Act of 2001 will diminish the pressure on the common law to provide for victims of personal injuries. The new legislation retains the no-fault principle and the prohibition on common law actions for compensatory damages. It does provide for lump-sum payments, but these relate to loss of body parts which are used in earning an income. These payments would not help many female victims of health crises.

Irrespective of what the new legislation may achieve, I think there is a strong social need to hold people accountable for their actions. The victims of personal injury, as well as the public at large, find it increasingly difficult to accept a "no-fault" principle. They want those responsible to be held accountable where blame is clearly an issue. The philosophy of a no-fault scheme which bars the individual from taking personal action to hold a tortfeasor accountable is increasingly at odds with current thinking. Today many in society place importance on holding individuals accountable for their actions and omissions. The notion of community assumption of responsibility for victims' injuries, irrespective of the circumstances of the injuries, seems naive and difficult to comprehend. This hardening of attitudes probably lies at the heart of the retreat from the original comprehensive scheme. A community which still believed that it should bear the responsibility for and, therefore, the costs of all victims' personal injuries, howsoever inflicted, would not be so concerned about the burgeoning costs associated with such a scheme. The new legislation has done nothing to address these questions. Yet without strong community support and willingness to pay for the costs of accidents any accident compensation scheme will operate ineffectively. In essence a community gets the accident compensation scheme it is prepared to pay for. For New Zealanders the retreat from a comprehensive scheme has replaced the usual lottery of litigation with a new lottery. And this one has left some victims with no chance of a financial remedy.

\section{CONCLUSION}

The plight of the female victims of health crises, who have received little or nothing under the ACC legislation, illustrates the scheme's failings. The legislation's history has demonstrated the scheme's inability to provide remedies to all victims of personal injury. Over time the scheme has developed its own vagaries. In response to these vagaries, victims increasingly resort to the common law. The legislation was designed to replace the common law and by implication to be better than the common law at providing a remedy for personal injury. The attempt to return to the common law can only be an indication that the scheme is failing to achieve its purpose. Unless the 
new legislation enables the scheme to achieve this purpose, pressure to revive the right to sue for compensatory remedies will continue to grow. 
